\title{
POLA KONSUMSI PANGAN RUMAH TANGGA PETANI HUTAN KEMASYARAKATAN DI KABUPATEN LAMPUNG BARAT
}

\author{
(Food Consumption Pattern of Social Forestry Farmer Household \\ In West Lampung Regency) \\ Asih Sulistyorini Uly Damora ${ }^{1}$, Faisal Anwar ${ }^{2}$, dan Yayat Heryatno ${ }^{2}$ \\ ${ }^{1}$ Program Studi Manaj emen Ketahahan Pangan (MKP), Sekolah Pascasarjana, IPB. \\ 2 Departemen Gizi Masyarakat, Fakultas Ekologi Manusia (FEMA), IPB \\ Tel: 0251-8628304/ 8621258; Fax: 0251-8625846/8622276.
}

\begin{abstract}
The aims of research were to 1) identify economic and social characteristic of $\mathrm{HKm}$ farmer household 2) analyze food consumption pattern of $\mathrm{HKm}$ farmer household 3) analyze requirement of food of $\mathrm{HKm}$ farmer household 4) analyze factors influencing level of energy and protein consumption sufficiency of HKm farmer household. Design research is cross-sectional study with the sampel size 90 selected by stratified random sampling. Foods consumed are rice, cassava, salted food, tempe, spinach and banana. Consumption of energy was $2020 \mathrm{kcal}$ per capita per day and consumption of protein equal to $47.9 \mathrm{gram}$ per capita per day. Level of household energy consumption sufficiency is $84.4 \%$ as good and protein consumption sufficiency $46.6 \%$ as good. Energy consumption sufficiency was influenced by the household size and household expenditure of food, while level of protein consumption sufficiency was influenced by household expenditure of food.
\end{abstract}

Key words: Food consumption pattern, social forestry

\section{PENDAHULUAN}

Kabupaten Lampung Barat dibentuk berdasarkan UU No. 6 Tahun 1991 dengan total luas 474989 hektar dan sebesar $76.36 \%$ atau 369362.37 hektar adalah kawasan hutan. Seki$\operatorname{tar} 23.64 \%$ dari luas wilayah yang dapat digunakan/dikelola sebagai areal budi daya pertanian, perkebunan dan perikanan darat untuk penghasil pangan sehingga membutuhkan strategi kebijakan khusus dalam pembangunan dan pengelolaan lingkungannya untuk menjamin ketahanan pangan masyarakat. Salah satu upaya yang dilakukan untuk menjamin ketahanan pangan adalah melaksanakan pemantauan konsumsi untuk mengetahui permasalahan pangan dan gizi yang sering terjadi di daerah pedesaan termasuk penduduk yang tinggal di sekitar kawasan hutan dan menggantungkan hidupnya pada hutan.

Pengelolaan Hutan Kemasyarakatan/ $\mathrm{HKm}$ (Community Based Forest Management (CBFM) merupakan salah satu Program/kebijakan yang diyakini merupakan salah satu strategi pembangunan/pengelolaan lahan yang dapat mendukung ketersedian pangan rumah tangga karena program ini memberikan peluang bagi masyarakat lokal untuk memanfaatkan lahan hutan lindung dengan menanami- nya dengan berbagai jenis tanaman sumber produksi pangan. Selain itu hasil tanamannya dapat dijual untuk memperoleh pendapatan guna meningkatkan daya beli pangan untuk memenuhi kebutuhan konsumsi pangan rumah tangga. Selama ini belum diketahui bagaimana kondisi ketahanan pangan masyarakat pengelola Hutan Kemasyarakatan dari sisi konsumsinya. Kondisi ini sangat penting karena akan memberikan data dan informasi serta akan menentukan langkah-langkah yang akan dilakukan untuk pembangunan kedepan dan juga antisipasi dan penyelesaian jika terjadi masalah ketahanan pangan. Berdasarkan hal tersebut di atas penulis merasa perlu untuk melakukan penelitian tingkat konsumsi rumahtangga petani Hutan Kemasyarakatan.

Penelitian ini bertujuan untuk menganalisis pola konsumsi pangan rumah tangga petani Hutan Kemasyarakatan di Kabupaten Lampung Barat dengan tujuan khusus 1) mengidentifikasi karakteristik sosial ekonomi rumah tangga petani Hkm; 2) menganalisis pola konsumsi pangan rumah tangga Petani HKm; 3) menganalisis kebutuhan pangan rumah tangga petani $\mathrm{HKm}$; 4) menganalisis faktor-faktor yang mempengaruhi tingkat kecukupan konsumsi energi dan protein rumah tangga petani $\mathrm{HKm}$. Penelitian ini diharapkan dapat memberikan 
informasi tentang pola konsumsi pangan rumah tangga petani Hutan Kemasyarakatan guna usaha peningkatan ketahanan pangan rumah tangga petani $\mathrm{HKm}$ dan perencanaan kebijakan Hutan Kemasyarakatan untuk mendukung program ketahanan pangan Kabupaten Lampung Barat.

\section{METODE PENELITIAN}

\section{Desain dan Tempat Penelitian}

Desain penelitian yang digunakan adalah cross-sectional study pada bulan oktober sampai desember 2008. Populasi adalah rumahtang ga petani $\mathrm{HKm}$ dengan ukuran sampel 90 rumah tangga yang dipilih secara proporsional random sampling berdasarkan ukuran kelompok.

\section{Jenis dan Cara Pengumpulan Data}

Data yang digunakan dalam penelitian ini meliputi data primer dan data sekunder. Pengambilan data primer dilakukan dengan pengamatan di lapangan dan wawancara langsung dengan menggunakan kuesioner meliputi 1) karakteristik sosial ekonomi rumah tangga, 2) pola konsumsi pangan rumah tangga yang dipengaruhi oleh frekuensi dan kebiasaan makan serta preferensi bahan pangan, 3) konsumsi pangan yang meliputi konsumsi energi dan protein.

\section{Pengolahan dan Analisis Data}

Pengolahan data dilakukan dengan cara: 1) Data karakteristik rumah tangga dianalisis secara deskriptif; 2) Pola konsumsi ditetapkan berdasarkan frekuensi makan, jenis bahan pangan yang dikonsumsi, jumlah konsumsi energi dan protein serta mutu konsumsi pangan (PPH). Konsumsi energi dan protein dihitung dengan menggunakan Daftar Komposisi Bahan Makanan (DKBM); 3) Kecukupan Energi dan Protein diperoleh dengan menganalisis secara deskriptif berdasarkan AKG yang ideal hasil dari Widyakarya Nasional Pangan dan Gizi tahun 2004. Tingkat Kecukupan zat gizi dihitung dengan membagi konsumsi zat gizi dengan tingkat kecukupan kemudian dikalikan 100\% dan diklasifikasikan menurut Suhardjo (1995) yaitu baik, cukup, kurang, dan buruk. 4) melakukan penghitungan PPH; 5) Untuk mengetahui faktor-faktor yang mempengaruhi tingkat kecukupan konsumsi energi dan protein dilakukan analisis regresi linier.

\section{HASIL DAN PEMBAHASAN}

\section{Karakteristik Rumah tangga Contoh}

Rata-rata jumlah anggota rumah tangga contoh adalah 4 orang dengan kisaran 1 sampai 7 orang. Sebesar $22.2 \%$ memiliki anggota rumahtangga $>4$ orang dan $77.8 \%$ memiliki anggota rumah tangga $<4$ orang. Rata-rata umur kepala rumah tangga adalah 42 tahun dengan kisaram 24-72 tahun dan umur ibu rumah tangga adalah 36 tahun dengan kisaran umur 18-62 tahun. Rata-rata lama pendidikan formal kepala rumah tangga adalah 7.1 tahun dengan kisaran 0-12 tahun sedangkan ibu rumah tangga 6.7 tahun dengan kisaran lama pendidikan 0-16 tahun. Sebagian besar suku kepala dan ibu rumah tangga adalah Sunda dan J awa. Pendapatan rata-rata rumah tangga responden per kapita per bulan adalah Rp511 780 dengan kisaran Rp. 206965 - Rp. 1415 875, lebih besar dari standar kemisinan nasional yaitu Rp. 146837 per kapita per bulan dan untuk Propinsi Lampung Rp. 145637.00 per kapita per bulan (BPS, 2008). Pengeluaran rata-rata rumah tangga adalah Rp. 416062 dengan kisaran antara Rp. 145637 - Rp. 1021 641. Proporsi pengeluaran pangan rata-rata rumah tangga ialah $52.38 \%$ dari total pengeluaran, dengan rata-rata pengeluaran pangan per kapita per bulan adalah Rp. 216706 dengan jumlah terendah Rp. 130944 dan tertinggi Rp. 328891.

Sayuran dan buah yang paling sering dikonsumsi adalah bayam, kangkung, kacang panjang, pisang dan pepaya. Umbi yang paling banyak dikonsumsi adalah singkong dengan berat rata-rata 32.7 gram per kapita per hari atau $12 \mathrm{~kg}$ per kapita per tahun. Konsumsi umbi-umbian sangat sedikit diduga selain karena tidak terbiasa juga karena umbi-umbian tidak banyak tersedia di lokasi akibat hama babi hutan yang akan mengganggu umbi-umbian yang ditanam di lahan garapan. Kelompok pangan hewani yang paling banyak dikonsumsi adalah ikan segar dengan rata-rata 20.4 gram per kapita per hari atau $7.5 \mathrm{~kg}$ per kapita per tahun. Konsumsi daging rata-rata hanya $1 \mathrm{gram}$ per kapita per hari atau $0.4 \mathrm{~kg}$ per kapita per tahun.

Konsumsi tempe 29.6 gram per kapita per hari dan tahu 29.3 gram per kapita per hari. Kelompok sayur dan buah yang paling banyak dikonsumsi adalah sawi 16.3 gram per kapita per hari dan pisang 85.2 gram per kapita per hari.

Sayur dan buah konsumsinya cukup tinggi diduga karena mudah didapatkan di lokasi 
baik dari produksi sendiri, dari kebun tetangga maupun membeli.

Minyak sawit dikonsumsi setiap hari dengan berat rata-rata 29.3 gram per kapita per hari, kelapa dikonsumsi 18 gram per kapita per hari dan gula pasir dikonsumsi rata-rata 35 gram per kapita per hari. Besarnya konsumsi mi- nyak dan gula pasir disebabkan kebiasaan rumah tangga menggoreng makanan selingan yang konsum-sinya dibarengi dengan minum kopi dan teh. Semakin sering dan semakin berat suatu pangan dikonsumsi semakin besar peluang pangan tersebut tergolong ke dalam pola konsumsi (Pranadji, 1988).

\section{Konsumsi Energi dan Protein}

Konsumsi energi rumah tangga terbesar berasal dari padi-padian, minyak dan lemak serta sayur dan buah sedangkan terkecil dari buah biji berminyak. Konsumsi energi 2020 kkal mencerminkan bahwa konsumsi energi rumah tangga telah mencukupi konsumsi yang dianjurkan yaitu 2000 Kkalori. Tabel 2. Konsumsi energi dan protein rumah tangga petani $\mathrm{HKm}$.

Konsumsi protein rata-rata rumah tangga hanya 47.9 gram, jumlah ini masih kurang jika dibandingkan dengan konsumsi ideal sebesar 52 gram. Kontribusi terbesar juga berasal dari padi-padian, diikuti oleh pangan hewani dan kacang-kacangan. Konsumsi energi dan protein rumah tangga petani $\mathrm{HKm}$ dapat dilihat pada Tabel 2.

Persentase tingkat kecukupan konsumsi energi rumah tangga adalah baik $85.6 \%$ dan cukup $15.6 \%$ Sementara itu $46.7 \%$ rumah tangga memiliki kecukupan protein yang baik, sisanya $<0 \%$ Artinya bahwa tingkat konsumsi protein masih harus ditingkatkan lagi terhadap 53.3 \% rumah tangga agar dapat hidup sehat. Suhardjo (1995) menyatakan bahwa rumahtangga dikategorikan memiliki kecukupan energi dan protein yang baik apabila tingkat kecukupannya terhadap standar ideal $>90 \%$

Tabel 1. J umlah Bahan Makanan yang Dikonsumsi Rumah Tangga Petani HKm

\begin{tabular}{lrrrr}
\hline \multicolumn{1}{c}{ Bahan Makanan } & \multicolumn{2}{c}{ Gram Per kapita/hari } & \multicolumn{2}{c}{ Kilogram Per kapita/tahun } \\
& Rata-rata & Sd & Rata-rata & Sd \\
\hline Beras & 268.9 & 37.5 & 98.2 & 13.7 \\
Mie & 10.7 & 8.4 & 3.9 & 3.3 \\
Singkong & 32.7 & 41.7 & 12.0 & 15.2 \\
Ubi jalar & 4.5 & 10.5 & 1.7 & 3.8 \\
Ikan asin & 13.8 & 8.2 & 5.0 & 3.0 \\
Ikan segar & 20.4 & 15.5 & 7.5 & 5.7 \\
Telur & 18.7 & 18.7 & 6.8 & 6.8 \\
Daging & 1.0 & 3.6 & 0.4 & 1.3 \\
Tempe & 29.6 & 21.2 & 10.8 & 7.7 \\
Tahu & 23.4 & 20.9 & 8.5 & 7.6 \\
Sawi & 16.3 & 30.0 & 5.9 & 11.0 \\
Pisang & 85.2 & 77.0 & 31.1 & 28.1 \\
Minyak sawit & 29.3 & 13.2 & 10.7 & 4.8 \\
Kelapa & 18 & 18.9 & 6.6 & 6.9 \\
Gula & 35.3 & 7.1 & 12.9 & 2.6 \\
\hline
\end{tabular}

Tabel 2. Konsumsi Energi dan Protein Rumah Tangga Petani HKm

\begin{tabular}{lrrrrrrrr}
\hline \multicolumn{1}{c}{ Kelompok } & \multicolumn{4}{c}{ Konsumsi Energi } & \multicolumn{4}{c}{ Konsumsi Protein } \\
\cline { 2 - 9 } \multicolumn{1}{c}{ Pangan } & Min & \multicolumn{1}{c}{ Maks } & Rata-rata & \multicolumn{1}{c}{ Sd } & Min & Maks & Rata-rata & Sd \\
\hline Padi-padian & 455 & 1483 & 1019 & 146 & 8.7 & 28.2 & 19.5 & 2.8 \\
Umbi-umbian & 0 & 234 & 45 & 51 & 0 & 2.07 & 0.5 & 0.5 \\
Pangan Hewani & 18 & 224 & 82 & 40 & 3.8 & 21.1 & 10.2 & 3.9 \\
Minyak dan Lemak & 74 & 771 & 279 & 114 & 0 & 0.2 & 0 & 0 \\
Buah biji berminyak & 0 & 127 & 29 & 24 & 0 & 2.1 & 0.6 & 0.4 \\
Kacang-kacangan & 18 & 356 & 92 & 63 & 2.2 & 24.4 & 9.2 & 5.5 \\
Gula & 99 & 386 & 194 & 54 & 0 & 0.7 & 0.0 & 0.1 \\
Sayur dan buah & 14 & 702 & 227 & 150 & 0.7 & 26.0 & 5.2 & 3.8 \\
Lainnya & 15 & 95 & 53 & 17 & 0.8 & 4.8 & 2.7 & 0.8 \\
Total & 693 & 4378 & 2020 & 659 & 16.2 & 109.6 & 47.9 & 17.8 \\
\hline
\end{tabular}




\section{Pola Pangan Harapan}

Secara umum konsumsi energi rumah tangga petani $\mathrm{HKm}$ mencapai $2020 \mathrm{Kkal}$ per kapita per hari atau mencapai $101 \%$ dari angka konsumsi yang dianjurkan yaitu 2000 Kkal/ kapita per hari. Pola Pangan Harapan rumah tangga dapat dilihat pada Tabel 3.

J umlah skor total PPH 81.7 dan komposisinya dari seluruh kelompok pangan menunjukkan bahwa pangan yang memberikan kontribusi energi yang telah memenuhi standar ideal baru dipenuhi oleh kelompok padipadian, minyak dan lemak, buah biji berminyak, gula, sayur dan buah serta kelompok lainnya. Kelompok umbi-umbian serta pangan hewani, kacang-kacangan dan buah biji berminyak harus ditambah lagi konsumsinya.

Konsumsi umbi-umbian, pangan hewani, kacang-kacangan masih rendah diduga dikarenakan lokasi tempat tinggal rumah tangga contoh yang berada di sekitar hutan yang berjarak puluhan kilometer dari pasar menyebabkan jauh dari akses pangan sehingga pangan tersebut sulit. Antang (2002) menyatakan bahwa konsumsi bahan pangan berbeda pada masingmasing kelompok masyarakat dimana faktor ekologi memberikan pengaruh yang besar pada pola konsumsi. Melihat hal tersebut di atas upaya peningkatan konsumsinya dapat dilakukan melalui penggunaan bahan pangan yang mudah didapatkan di lokasi sekitar tempat tinggal dan menambah penyediaannya untuk dikonsumsi rumah tangga dengan memanfaatkan lahan garapan dengan beternak, membuat kolam dan menanam umbi-umbian serta kacang-kacangan.

Untuk mendukung upaya tersebut pemerintah dapat berperan melalui dinas dan instansi yang terkait untuk memberikan bantuan berupa bibit tanaman dan ikan serta hewan ternak untuk dibudidayakan oleh rumah tangga. Selain itu pemerintah perlu melakukan upaya untuk meningkatkan akses terhadap pa- ngan dengan membangun sarana dan prasarana transportasi serta pasar serta peningkatan kesadaran rumah tangga akan pentingnya konsumsi pangan yang ideal mengingat lokasi rumah tangga yang berada di sekitar hutan sehingga kurang mendapatkan penyuluhan, pemberian informasi, pelatihan dan sosialisasi.

\section{Kebutuhan Pangan Ideal}

Rumah tangga petani HKm memiliki pola konsumsi pangan aktual yang belum memenuhi standar kebutuhan ideal. Kebutuhan pangan ideal ini dimaksudkan agar kualitas makanan yang dikonsumsi rumah tangga baik dan komposisinya berimbang meskipun dengan pola konsumsi yang sama. Kebutuhan pangan ideal dihitung dengan menggunakan pola konsumsi pangan aktual dibandingkan dengan konsumsi pangan ideal dari setiap kelompok pangan.

Data yang disajikan pada menunjukkan bahwa bahwa terdapat gap konsumsi energi beras sebesar $18 \mathrm{Kkal}$ atau setara dengan 5 gram. Artinya bahwa selama ini konsumsi beras sudah melebihi kompisisi ideal dan harus dikurangi sebesar 5 gram per kapita per hari dan energinya dapat digantikan dengan menambah konsumsi umbi sebesar 43.3 gram per kapita per hari.

Faktor Yang Mempengaruhi Tingkat Kecukupan Konsumsi Energi dan Protein

Analisis regresi linier menunjukkan:

1. Tingkat kecukupan konsumsi energi dipengaruhi oleh pengeluaran yang pangan menunjukkan hubungan positif yang nyata $(p<0.05)$ terhadap tingkat kecukupan konsumsi energi. Artinya adalah bahwa semakin besar pengeluaran pangan rumah tangga maka semakin banyak jumlah makanan sumber energi yang dapat disediakan untuk dikonsumsi oleh rumah tangga. Selain itu jumlah anggota rumah tangga menunjukkan

Tabel 3. Pola Pangan Harapan Rumah Tangga Contoh

\begin{tabular}{|c|c|c|c|c|c|c|}
\hline Kelompok Pangan & $\begin{array}{c}\text { Konsumsi Energi } \\
\text { (Kkal) }\end{array}$ & $\%$ Total & $\%$ AKE & Bobot & Skor PPH & $\begin{array}{l}\text { Skor } \\
\text { Maks }\end{array}$ \\
\hline Padi- padian & 1019 & 50.45 & 50.95 & 0.5 & 25 & 25 \\
\hline Umbi-umbian & 45 & 2.23 & 2.25 & 0.5 & 1.1 & 2.5 \\
\hline Pangan Hewani & 82 & 4.06 & 4.10 & 2 & 8.2 & 24 \\
\hline Minyak dan Lemak & 279 & 13.81 & 13.95 & 0.5 & 5 & 5 \\
\hline Buah Biji Berminyak & 29 & 1.44 & 1.45 & 0.5 & 0.7 & 1 \\
\hline Kacang-kacangan & 92 & 4.55 & 4.60 & 2 & 9.2 & 10 \\
\hline Gula & 194 & 9.60 & 9.70 & 0.5 & 2.5 & 2.5 \\
\hline Sayur dan buah & 227 & 11.24 & 11.35 & 5 & 30 & 30 \\
\hline Lain-lain & 53 & 2.62 & 2.65 & 0 & 0 & 0 \\
\hline J umlah & 2020 & 100.00 & 101.00 & & 81.7 & 100 \\
\hline
\end{tabular}


Tabel 4. Kebutuhan Pangan Ideal Rumah Tangga Petani HKm

\begin{tabular}{|c|c|c|c|c|c|c|c|}
\hline Kelompok Pangan & $\begin{array}{c}\text { Keb pangan } \\
\text { aktual (gr) }\end{array}$ & $\begin{array}{l}\text { Energi } \\
\text { aktual } \\
\text { (Kkal) }\end{array}$ & $\begin{array}{l}\text { \% energi } \\
\text { aktual }\end{array}$ & $\begin{array}{c}\text { Energi } \\
\text { ideal } \\
\text { (KKal) }\end{array}$ & $\begin{array}{l}\text { \% Energi } \\
\text { ideal }\end{array}$ & $\begin{array}{c}\text { Gap kons } \\
\text { energi } \\
\text { (Kkal) }\end{array}$ & $\begin{array}{c}\text { Gap } \\
\text { Keb pangan } \\
\text { (gr) }\end{array}$ \\
\hline Padi-padian & 288.1 & 1019 & 50.4 & 1000 & 50.0 & -19 & \\
\hline Umbi-umbian & 43.5 & 45 & 2.2 & 120 & 6.0 & -75 & \\
\hline Singkong & 32.8 & 36 & 1.8 & 95 & 4.7 & 59 & 30.2 \\
\hline Pangan Hewani & 62.8 & 82 & 4.0 & 240 & 12.0 & 158 & \\
\hline Minyak dan Lemak & 31.4 & 279 & 13.8 & 200 & 10.0 & -79 & \\
\hline Minyak sawit & 29.3 & 264 & 13.0 & 189 & 9.5 & -75 & -8.3 \\
\hline Buah biji berminyak & 19.3 & 29 & 1.4 & 60 & 3.0 & 31 & \\
\hline Kelapa & 18.0 & 22 & 1.0 & 45 & 2.2 & 23 & 18.9 \\
\hline Kacang-kacangan & 63.4 & 92 & 4.5 & 100 & 5.0 & 8 & \\
\hline Tempe & 29.6 & 44 & 2.1 & 48 & 2.4 & 4 & 2.6 \\
\hline Pisang & 85.2 & 63 & 3.1 & 33 & 1.6 & -30 & -22.6 \\
\hline
\end{tabular}

hubungan negatif yang nyata $(p \varangle 0.05)$ terhadap tingkat kecukupan konsumsi energi. Artinya bahwa semakin besar anggota rumah tangga maka semakin kecil tingkat konsumsi energi karena semakin banyak anggota rumah tangga yang harus dibagi. Menurut Den Hartog et al. (1995) ukuran rumah tangga (household size) merupakan penentu dalam konsumsi energi. Semakin besar ukuran rumah tangga, maka semakin sedikit pangan tersedia yang yang dapat didistribusikan pada anggota rumah tangga.

2. Tingkat kecukupan konsumsi protein dipengaruhi oleh faktor pengeluaran pangan yang menunjukkan hubungan positif yang sangat nyata $(p \varangle 0.01)$ terhadap tingkat kecukupan konsumsi protein. Hal ini menunjukkan bahwa semakin besar besar pengeluaran rumah tangga membeli pangan maka semakin besar jumlah pangan sumber protein yang dapat disediakan untuk dikonsumsi oleh rumah tangga.

\section{KESIMPULAN}

Sebagian besar rumah tangga petani $\mathrm{HKm}$ merupakan rumah tangga kecil (77.8\%) dengan usia produktif 30-49 tahun dan ratarata pendidikan 6-7 tahun. Suku kepala dan ibu rumah tangga didominasi oleh Sunda dan Jawa. Pendapatan rata-rata rumah tangga responden adalah Rp. 509626 per kapita per bulan dan besarnya pengeluaran pangan rata-rata Rp. 213136 per kapita per bulan.

Pangan yang dikonsumsi rumah tangga adalah makanan pokok beras, lauk hewani berupa ikan asin dan ikan segar, lauk nabati berupa tempe dan tahu, sayur dan buah adalah bayam, kangkung, sawi, pisang, dan pepaya serta mengonsumsi minyak, gula dan kelapa.

Konsumsi energi rata-rata rumah tangga contoh adalah 2020 Kkal per kapita per hari dan konsumsi protein sebesar 47.9 gram per kapita per hari. Tingkat kecukupan konsumsi energi rumah tangga adalah baik sebesar $84.4 \%$ untuk energi dan $46.6 \%$ baik untuk protein dengan skor PPH 81.7.

Kebutuhan pangan ideal per kapita adalah beras sebesar $263.9 \mathrm{gram} / \mathrm{hari}$, singkong $62.5 \mathrm{gram} / \mathrm{hari}$, ikan asin $26.8 \mathrm{gram} / \mathrm{hari}$, ikan segar $26.8 \mathrm{gram} /$ hari, minyak sawit $21 \mathrm{gram} /$ hari, kelapa $36.9 \mathrm{gram} / \mathrm{hari}$, tempe $32.2 \mathrm{gram}$ / hari, gula pasir $18.2 \mathrm{gram} /$ hari, sawi 10.9 gram/ hari dan pisang sebesar $62.6 \mathrm{gram} / \mathrm{hari}$.

Faktor yang berpengaruh terhadap tingkat kecukupan konsumsi energi adalah jumlah anggota rumah tangga dan pengeluaran pangan rumah tangga sedangkan tingkat kecukupan konsumsi protein dipengaruhi oleh pengeluaran pangan rumah tangga.

\section{DAFTAR PUSTAKA}

Antang. 2002. Ketahanan Pangan dan Kebiasaan Makan Rumah Tangga pada Masyarakat yang Tinggal di Daerah Sekitar Lahan Gambut Kalimantan Tengah. Tesis Magister. IPB, Bogor.

Den Hartog AP, Van steveren WA, \& Brouwer ID. 1995. Manual for Social Surveys on Food Habits and Consumption in Developing Countries. Margraf Verlag, Weikersheim. 
Pranadji DK. 1988. Perilaku Konsumsi Makan Keluaraga Peserta Taman Gizi. Tesis Magister. IPB, Bogor.
Suhardjo. 1995. Sosio Budaya Gizi. Departemen Pendidikan dan Kebudayaan. Direktorat Jendral Pandidikan Gizi. Pusat Antar Universitas Pangan dan Gizi. IPB, Bogor. 